\title{
Hubungan Indeks Kepribadian Dasar Minnesota Multiphasic Personality Inventory -2 (MMPI-2) Adaptasi Indonesia dengan Supplementary Scale College Maladjustment pada Mahasiswa Fakultas Kedokteran Semester 1 Tahun Ajaran 2018/2019 Universitas Sam Ratulangi Manado
}

\author{
${ }^{1}$ Vini S. A. Pontoh \\ ${ }^{2}$ Theresia M. D. Kaunang \\ ${ }^{2}$ Herdy Munayang
}

${ }^{1}$ Program Studi Pendidikan Dokter Fakultas Kedokteran Universitas Sam Ratulangi Manado
${ }_{2}$ Bagian Ilmu Kedokteran Jiwa Fakultas Kedokteran Universitas Sam Ratulangi
Email: vinipontoh@gmail.com

\begin{abstract}
Students are faced to many demands as well as new reponsibilities, due to changes of several individual functional aspects such as physical, physiology, as well as social aspects. It is expected that a student can apply his/her knowledge to the community life. The common problem faced by the students is inability to adapt to a new environment. Personality is an individual characteristic that is relatively constant, which affects the individual adjustment to the environment. By performing the Indonesian adaptation of MMPI-2 test, we can observe the psychological and personality development that will affect these students in facing future challenges. This study was aimed to determine the correlation between basic personality index (OCEAN) and Supplementary Scale (College Maladjustment) in the first year students of Medical Faculty of Sam Ratulangi University for academic year of 2018/2019. This was an analytical observational study withh a cross sectional design. Data were analyzed by using the Spearman Rank correlation method. The results showed a significant strong correlation $(P=0.000 ; \mathrm{R}=-0.663$, negative direction). Conclusion: There was a significant relationship between OCEAN index and College Maladjustment in the first year students of Medical Faculty of Sam Ratulangi University for academic year of 2018/2019.
\end{abstract}

Keywords: MMPI-2, basic personality index, OCEAN index, college maladjustment

\begin{abstract}
Abstrak: Mahasiswa dihadapkan dengan berbagai tuntutan dan tugas baru disertai perubahan pada beberapa aspek fungsional individu seperti fisik, psikologis dan juga sosial. Seorang mahasiswa diharapkan dapat menerapkan ilmu yang dimiliki ke dalam kehidupan masyarakat. Permasalahan yang sering dialaminya yaitu sulit beradaptasi pada lingkungan baru. Kepribadian merupakan ciri seorang individu melakukan interaksi dan berreaksi dengan individu lainnya. Kepribadian memiliki karakteristik di dalam diri individu yang relatif menetap, bertahan, yang memengaruhi penyesuaian diri individu terhadap lingkungan. Dengan melakukan tes MMPI-2 adaptasi Indonesia, dapat dilihat perkembangan psikologis serta kepribadian yang akan memengaruhi mahasiswa tersebut dalam menghadapi tantangan yang akan datang. Penelitian ini bertujuan untuk mengetahui hubungan indeks kepribadian dasar OCEAN dengan Supplementary Scale College Maladjustment pada Mahasiswa Fakultas Kedokteran Program Studi Pendidikan Dokter Semester 1 Tahun Ajaran 2018/2019 Universitas Sam Ratulangi Manado. Jenis penelitian ialah observasional analitik dengan desain potong lintang. Data penelitian dianalisis menggunakan metode korelasi Spearman Rank. Hubungan Indeks OCEAN dengan skor College Maladjusment mendapatkan $\mathrm{p}=0,000$ dengan kekuatan kuat $(\mathrm{R}=-0,663$, arah negatif). Simpulan: Terdapat hubungan yang bermakna dengan kekuatan kuat tetapi berbanding terbalik antara indeks OCEAN dengan College Maladjustment pada mahasiswa Fakultas Kedokteran Program Studi Pendidikan Dokter semester 1 tahun ajaran 2018/2019 Universitas Sam Ratulangi Manado.
\end{abstract}

Kata kunci: MMPI-2, indeks kepribadian dasar, indeks OCEAN, college maladjustment 
Kepribadian merupakan suatu ciri seorang individu melakukan interaksi dan bereaksi dengan individu lainnya. Hasil dalam kepribadian dapat bertemu bila terdapat penyesuaian antar kedua faktor yaitu faktor endogen dan faktor eksogen yang berdampak terhadap kepribadian yang berwujud dalam perubahan atau perkembangan. Kepribadian memiliki sebuah karakteristik di dalam diri individu yang relatif menetap, bertahan, yang memengaruhi penyesuaian diri individu terhadap lingkungan. ${ }^{1}$

Mahasiswa adalah sebuah kelompok yang berintelektual dalam hal-hal akademik. Seorang mahasiswa diharapkan dapat menerapkan ilmu yang dimiliki ke dalam kehidupan masyarakat. Permasalahan yang sering dialami oleh mahasiswa yaitu sulit beradaptasi pada lingkungan yang baru. Lama waktu yang diperlukan tergantung dari mahasiswa tersebut. Keberhasilan mahasiswa dalam menyesuaikan diri pada tahun pertama kuliah dapat diprediksikan dalam mencapai keberhasilan akademik. Sebaliknya, kegagalan dalam hal menyesuaikan diri dengan lingkungan baru bisa menyebabkan gangguan psikologis dan perasaan rendah diri pada individu bersangkutan karena adanya perbedaan latar belakang yang dimiliki oleh mahasiswa tersebut. $^{2}$

Mahasiswa dapat digolongkan pada 2 tahap yaitu remaja akhir dan dewasa awal, yang usianya sekitar 18-21 tahun dan 22-24 tahun. Mahasiswa mengalami masa peralihan dan dihadapkan dengan berbagai tuntutan serta tugas baru. Pada masa ini terjadi perubahan beberapa aspek fungsional individu seperti fisik, psikologis dan juga sosial. ${ }^{3}$

Penelitian yang dilakukan Palempung et al. ${ }^{4}$ terhadap mahasiswa kedokteran semester 1 tahun ajaran 2013/2014 dengan menggunakan Supplementary Scale Minnesota Multiphasic Personality Inventory-2 (MMPI-2) adaptasi Indonesia sebanyak 101 responden, menunjukkan adanya hasil tinggi pada skala college maladjustment sebanyak 26 orang, terdiri dari 7 orang laki-laki dan 19 orang perempuan dengan persentase $25,7 \% .^{4}$ Penelitian yang dilakukan oleh Muktamiroh et $\mathrm{al}^{5}$ terhadap mahasiswa kedokteran di salah satu Fakultas Kedokteran di Indonesia dengan menggunakan MMPI-2, sebanyak 209 responden menun-jukkan adanya hasil indeks kepribadian dasar OCEAN yakni paling banyak kepribadian dasar sedang sebanyak 82 mahasiswa dengan persentase $39,2 \%$ dan diikuti dengan kepribadian dasar baik sebanyak 64 mahasiswa dengan persentase $30,6 \%{ }^{5}$

Berdasarkan teori dan hasil penelitian sebelumnya, maka dalam penelitian ini dilakukan pemeriksaan yang mengacu pada indeks kepribadian dasar OCEAN dan Supplementary Scale College Maladjustment pada mahasiswa Fakultas Kedokteran Program Studi Pendidikan Dokter semester 1 tahun ajaran 2018/2019 Universitas Sam Ratulangi. Dalam pendekatan tes kepribadian ini, responden biasanya diberikan pertanyaan yang spesifik dan terstandar dalam format tertulis atau lisan yang terstruktur. Skor yang diperoleh kemudian dibandingkan dengan tabel normatif dan dikonversikan ke dalam skor standar atau persentil, atau keduanya, ${ }^{6}$ sehingga, MMPI2 merupakan tes yang paling cocok digunakan dalam mendiagnosis dan meneliti kesehatan mental seseorang.

\section{METODE PENELITIAN}

Jenis penelitian ini ialah observasional analitik dengan desain potong lintang. Responden penelitian ialah mahasiswa Fakultas Kedokteran Semester 1 Tahun Ajaran 2018/2019 Universitas Sam Ratulangi Manado. Variabel penelitian yaitu indeks kepribadian dasar OCEAN, Supplementary Scale College Maladjustment, dan sosio-demografi.

Penelitian ini melibatkan 72 responden. Setelah mendapat persetujuan responden, peneliti mengambil data menggunakan kuesioner MMPI-2 adaptasi Indonesia. Data penelitian disajikan dalam bentuk tabel dan diagram, serta dianalisis menggunakan metode korelasi Spearman Rank. 


\section{HASIL PENELITIAN}

Pada penelitian ini dilakukan analisis bivariat untuk menentukan adanya hubungan antara kedua variabel. Gambar 1 memperlihatkan bahwa sebagian besar responden yang berpartisipasi dalam penelitian ini ialah perempuan sebanyak 44 mahasiswa $(61,11 \%)$ sedangkan laki-laki sebanyak 28 mahasiswa $(38,89 \%)$.

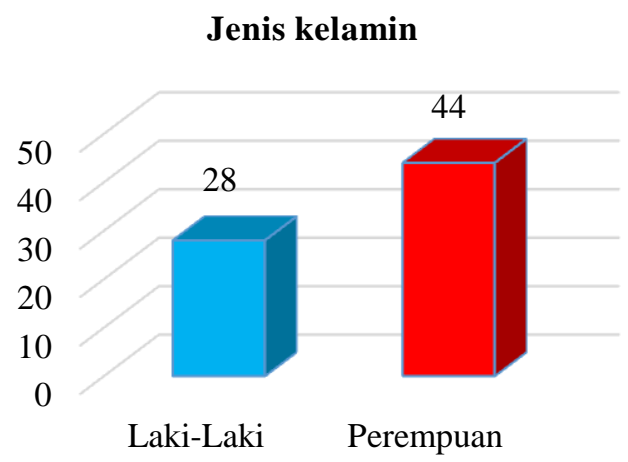

Gambar 1. Distribusi jumlah mahasiswa Fakultas Kedokteran Semester 1 Tahun Ajaran 2018/2019 Universitas Sam Ratulangi Manado berdasarkan jenis kelamin

Gambar 2 menunjukkan bahwa sebagian besar responden yang berpartisipasi dalam penelitian ini berusia 18 tahun dengan jumlah 57 mahasiswa $(79,17 \%)$, diikuti yang berusia 19 tahun dengan jumlah 13 mahasiswa $(18,06 \%)$ sedangkan yang berusia 20 tahun hanya sebanyak 2 mahasiswa $(6,67 \%)$.

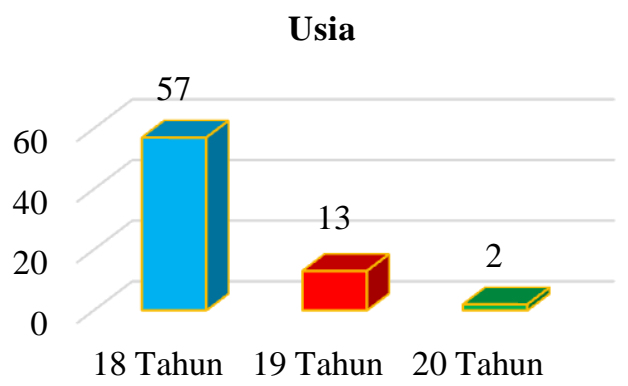

Gambar 2. Distribusi mahasiswa Fakultas Kedokteran Semester 1 Tahun Ajaran 2018/ 2019 Universitas Sam Ratulangi Manado berdasarkan usia

Gambar 3 menunjukkan sebagian besar responden penelitian ini berasal dari daerah luar Sulawesi Utara yaitu sebanyak 41 mahasiswa $(56,94 \%)$ sedangkan yang berasal dari Sulawesi Utara sebanyak 31 mahasiswa $(43,06 \%)$.

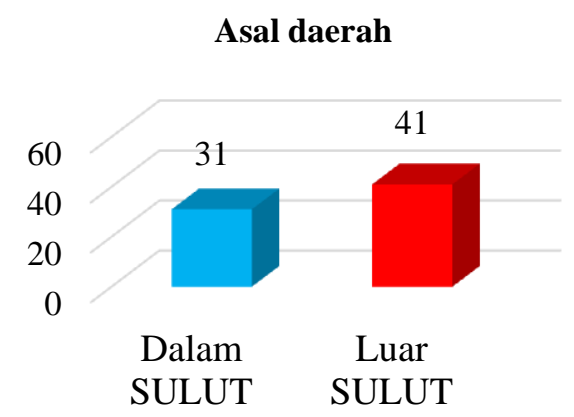

Gambar 3. Distribusi jumlah mahasiswa Fakultas Kedokteran Semester 1 Tahun Ajaran 2018/2019 Universitas Sam Ratulangi Manado berdasarkan asal daerah

Gambar 4 menunjukkan persentase terbanyak ialah responden yang memiliki jumlah dua saudara dan jumlah tiga saudara dengan hasil yang sama sebanyak 28 mahasiswa $(38,89 \%)$, diikuti oleh jumlah anak tunggal sebanyak 8 mahasiswa $(11,11 \%)$, yang memiliki empat saudara sebanyak 5 mahasiswa $(6,94 \%)$, yang memiliki jumlah tujuh saudara sebanyak 2 mahasiswa (2,78\%), dan yang paling sedikit yakni jumlah lima saudara sebanyak 1 mahasiswa $(1,39 \%)$.

\section{Jumlah saudara}

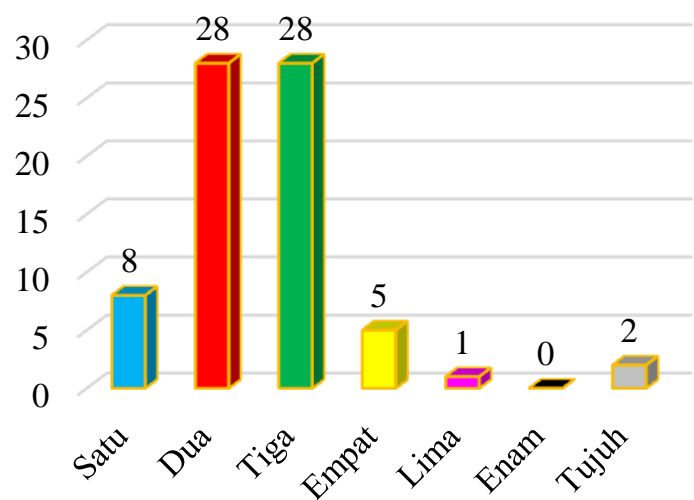

Gambar 4. Distribusi jumlah mahasiswa Fakultas Kedokteran Semester 1 Tahun Ajaran 2018/2019 Universitas Sam Ratulangi Manado berdasarkan jumlah saudara 
Gambar 5 menunjukkan persentase terbanyak ialah responden anak pertama (tunggal) sebanyak 39 mahasiswa $(54,17 \%)$, diikuti oleh anak kedua sebanyak 22 mahasiswa $(30,56 \%)$, anak ketiga sebanyak 7 mahasiswa $(9,72 \%)$, anak keempat sebanyak 2 mahasiswa $(2,78 \%)$, anak kelima dan anak ketujuh memiliki jumlah hasil yang sama sebanyak 1 mahasiswa (1,39\%).

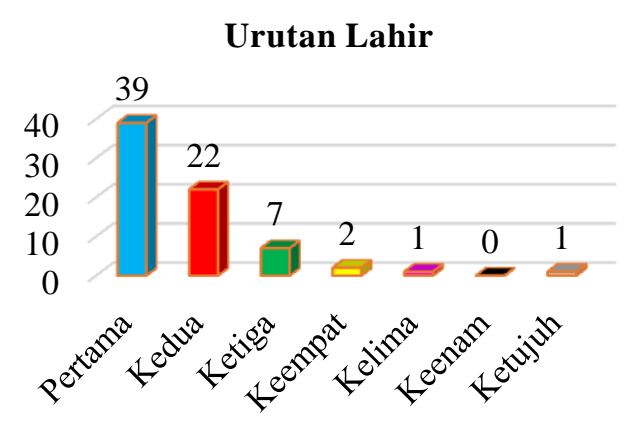

Gambar 5. Distribusi mahasiswa Fakultas Kedokteran Semester 1 Tahun Ajaran 2018/2019 Universitas Sam Ratulangi Manado berdasarkan anak ke

Tabel 1 menunjukkan bahwa dari 72 responden didapatkan indeks OCEAN dengan nilai signifikansi 0,012 (sig. $<0,05)$ pada uji Kolmogorov-Smirnov tetapi pada uji Shapiro-Wilk dengan nilai signifikansi 0,075 (sig.>0,05) yang menunjukkan data terdistribusi normal, sedangkan untuk skor setiap komponen OCEAN didapatkan signifikansi 0,00 (sig. $<0,05$ ) yang berarti data tidak terdistribusi normal.

Tabel 2 menunjukkan bahwa dari 72 responden didapatkan skor College Maladjustment dengan nilai signifikansi 0,200 ( $\operatorname{sig}>0,05$ ) pada uji Kolmogorov-Smirnov yang menunjukkan data terdistribusi normal.

Tabel 3 menunjukkan bahwa dari 72 responden didapatkan indeks OCEAN baik lebih dominan dibandingkan indeks OCEAN yang lain sebanyak 29 mahasiswa $(40,28 \%)$.

Tabel 4 menunjukkan bahwa dari 72 responden didapatkan skor normal/rata-rata lebih dominan daripada skor yang lain sebanyak 45 mahasiswa $(62,5 \%)$.

Tabel 5 menunjukkan bahwa hasil analisis bivariat menggunakan uji korelasi Spearman Rank mendapatkan nilai $P$ 0,000 $(P<0,05)$.

Tabel 1. Uji normalitas data indeks OCEAN dan komponen OCEAN

\begin{tabular}{lcccccc}
\hline & \multicolumn{3}{c}{ Kolmogorov-Smirnov $^{\mathrm{a}}$} & \multicolumn{3}{c}{ Shapiro-Wilk } \\
\cline { 2 - 7 } & Statistic & df & Sig. & Statistic & df & Sig. \\
\hline Indeks OCEAN &, 120 & 72 &, 012 &, 969 & 72 &, 075 \\
Skor Openness &, 271 & 72 &, 000 &, 810 & 72 &, 000 \\
Skor Conscientiousness &, 325 & 72 &, 000 &, 740 & 72 &, 000 \\
Skor Extraversion &, 260 & 72 &, 000 &, 813 & 72 &, 000 \\
Skor Agreeableness &, 312 & 72 &, 000 &, 777 & 72 &, 000 \\
Skor Neuroticism &, 229 & 72 &, 000 &, 825 & 72 &, 000 \\
\hline
\end{tabular}

Tabel 2. Uji Normalitas Data College Maladjustment

\begin{tabular}{lcccccc}
\hline & \multicolumn{3}{c}{ Kolmogorov-Smirnov $^{\text {a }}$} & \multicolumn{3}{c}{ Shapiro-Wilk } \\
\cline { 2 - 7 } & Statistic & df & Sig. & Statistic & df & Sig. \\
\hline Skor College Maladjustment &, 089 & 72 &, 200 &, 980 & 72 &, 304 \\
\hline
\end{tabular}


Tabel 3. Karakteristik responden berdasarkan indeks OCEAN

\begin{tabular}{ccc}
\hline $\begin{array}{c}\text { Indeks } \\
\text { OCEAN }\end{array}$ & $\begin{array}{c}\text { Jumlah } \\
(\mathbf{n})\end{array}$ & $\begin{array}{c}\text { Persentase } \\
(\boldsymbol{\%})\end{array}$ \\
\hline Sangat buruk & 1 & 1,39 \\
Buruk & 11 & 15,28 \\
Sedang & 27 & 37,50 \\
Baik & 29 & 40,28 \\
Sangat baik & 4 & 5,56 \\
Total & 72 & 100 \\
\hline
\end{tabular}

Tabel 4. Karakteristik responden berdasarkan Supplementary Scale College Maladjustment

\begin{tabular}{ccc}
\hline $\begin{array}{c}\text { Skor College } \\
\text { Maladjustment }\end{array}$ & Jumlah & $\begin{array}{c}\text { Persentase } \\
(\%)\end{array}$ \\
\hline Rendah & 18 & 25,00 \\
Normal/Rata-rata & 45 & 62,50 \\
Tinggi & 9 & 12,50 \\
Total & 72 & 100,00 \\
\hline
\end{tabular}

Tabel 5. Hasil analisis bivariat hubungan antara indeks OCEAN dengan skor College Maladjustment pada mahasiswa Fakultas Kedokteran Semester 1 Tahun Ajaran 2018/ 2019 Universitas Sam Ratulangi Manado

\begin{tabular}{cccc}
\hline \multirow{2}{*}{ Variabel } & \multicolumn{3}{c}{ Indeks OCEAN } \\
\cline { 2 - 4 } & $r$ hitung & $P$ value & $\mathrm{N}$ \\
\hline Skor College & $-0,663$ & 0,000 & 72 \\
Maladjustment & & & \\
\hline
\end{tabular}

\section{BAHASAN}

Hasil penelitian berdasarkan karakteristik sosio-demografi mendapatkan bahwa responden yang berpartisipasi dalam penelitian ini sebagian besar berjenis kelamin perempuan dengan jumlah sebanyak 44 mahasiswa $(61,11 \%)$ dibandingkan dengan yang berjenis kelamin laki-laki dengan jumlah sebanyak 28 mahasiswa $(38,89 \%)$. Hal ini menggambarkan bahwa yang berjenis kelamin perempuan lebih banyak dibandingkan berjenis kelamin laki-laki.

Pada penelitian ini usia responden dibagi menjadi 3 kelompok yaitu usia 18 tahun sebanyak 57 mahasiswa $(79,17 \%)$, usia 19 tahun sebanyak 13 mahasiswa $(18,06 \%)$, dan usia 20 tahun sebanyak 2 mahasiswa $(2,78 \%)$ yang menggambarkan bahwa usia 18 tahun merupakan kelompok usia dengan responden terbanyak.

Responden penelitian yang berasal dari dalam Sulawesi Utara lebih sedikit dibandingkan responden yang berasal dari luar Sulawesi Utara yaitu 31 mahasiswa $(38,89 \%)$ versus 41 mahasiswa $(61,11 \%)$.

Berdasarkan penelitian yang telah dilakukan didapatkan bahwa jumlah responden yang mempunyai dua saudara dan tiga saudara lebih banyak dibandingkan yang lain. Jumlah anak tunggal sebanyak 8 mahasiswa $(11,11 \%)$, jumlah dua saudara sebanyak 28 mahasiswa $(38,89 \%)$, jumlah tiga saudara sebanyak 28 mahasiswa $(38,89 \%)$, jumlah empat saudara sebanyak 5 mahasiswa $(6,94 \%)$, jumlah lima saudara sebanyak 1 mahasiswa (1,39\%); jumlah enam saudara tidak ada $(0 \%)$ dan jumlah tujuh saudara sebanyak 2 mahasiswa $(2,78 \%)$.

Hasil penelitian memperlihatkan bahwa jumlah anak pertama lebih dominan dibandingkan yang lain. Anak pertama (tunggal) sebanyak 39 mahasiswa $(54,17 \%)$, anak kedua sebanyak 22 mahasiswa $(30,56 \%)$, anak ketiga sebanyak 7 mahasiswa $(9,72 \%)$, anak keempat sebanyak 2 mahasiswa $(2,78 \%)$, dan anak kelima sebanyak 1 mahasiswa $(1,39 \%)$.

Penelitian indeks OCEAN pada komponen penelitian ini menggunakan penilaian skor yaitu skor 0 (Kurang), skor 1 (Sedang), skor 2 (Besar). Hasil skor yaitu skor 0-2 (sangat buruk), 3-4 (buruk), 5-6 (sedang), 7-8 (baik), dan 9-10 (sangat baik). Penelitian Supplementary Scale College Maladjustment pada penelitian ini menggunakan cut off score <50 rendah, 5065 normal/rata-rata, dan >65 tinggi. Berdasarkan kriteria MMPI-2 adaptasi Indonesia didapatkan 72 dari 76 mahasiswa semester 1 Fakultas Kedokteran Universitas Sam Ratulangi memiliki hasil valid.

Hasil analisis indeks OCEAN memperlihatkan yang paling banyak termasuk dalam kategori baik yaitu 29 mahasiswa (40,28\%); kategori sedang yaitu 27 mahasiswa (37,50\%); kategori buruk yaitu 11 mahasiswa $(15,28 \%)$; kategori sangat baik yaitu 4 mahasiswa $(5,56 \%)$; dan kategori yang paling sedikit yakni kategori sangat 
buruk yaitu 1 mahasiswa (1,39\%). Hal ini menunjukkan bahwa sebagian besar mahasiswa semester 1 Fakultas Kedokteran Program Studi Pendidikan Dokter Universitas Sam Ratulangi memiliki nilai keterbukaan pikiran, keterbukaan hati, keterbukaan terhadap orang lain, keterbukaan terhadap kesepakatan dan keterbukaan terhadap tekanan yakni baik (Indeks OCEAN 7-8). Berdasarkan penelitian Muktamiroh et al, ${ }^{5}$ didapatkan kategori sedang lebih dominan sebanyak 82 mahasiswa $(39,2 \%)$; hal ini diakibatkan karena jumlah responden yang diteliti lebih banyak dibandingkan penelitian ini.

Skala Openness (keterbukaan pikiran) menjelaskan bahwa komponen ini tidak bisa disamakan dengan keterbukaan diri. Komponen ini mengacu terhadap penerimaan ide-ide, pendekatan, dan pengalaman baru. Individu yang tertutup tidak selalu membela diri. Mereka juga tidak memiliki pikiran yang sempit dalam arti menghakimi dan intoleransi. Sebaliknya, mereka dicirikan oleh suatu pilihan yang akrab, praktis, konkrit, dan kurangnya minat dalam pengalaman untuk kepentingan diri sendiri. ${ }^{7,8}$ Dari hasil penelitian ini didapatkan nilai $P$ $<0,05$, sehingga dapat disimpulkan adanya hubungan antara Openness (keterbukaan pikiran) dengan skor College Maladjustment.

Skala Conscientiousness (keterbukaan hati) menjelaskan bahwa komponen ini ialah ukuran perbedaan individu dalam organisasi dan pencapaian. Individu yang sangat teliti, berbakti, dan disiplin tetapi juga ambisius dan pekerja keras kadangkadang menjadi workaholics. Laki-laki dan perempuan yang rendah dalam keterbukaan hati lebih bersifat lesu, santai, dan kurang menuntut pada diri sendiri ataupun orang lain. ${ }^{7,8}$ Dari hasil penelitian ini didapatkan nilai $P>0,05$ sehingga dapat disimpulkan tidak terdapat hubungan antara Conscientiousness (keterbukaan hati) dengan skor College Maladjustment.

Skala Extraversion (keterbukaan terhadap orang lain) menjelaskan bahwa komponen ini menyangkut perbedaan dalam pilihan untuk melakukan interaksi sosial dan aktivitas sehari-hari. Individu demikian umumnya dapat menstimulasi diri lebih baik terhadap lingkungannya, sedangkan untuk yang tidak memiliki keterbukaan terhadap orang lain lebih suka menyendiri atau dengan beberapa teman dekat. Individu dengan tipe ini biasanya pendiam, serius, menghargai kemandirian dan lebih memilih lingkungan yang tenang. ${ }^{7,8}$ Hasil penelitian ini mendapatkan nilai $P<0,05$ sehingga dapat disimpulkan terdapat hubungan antara Extraversion (keterbukaan terhadap orang lain) dengan skor College Maladjustment.

Skala Agreeableness (keterbukaan terhadap kesepakatan) menjelaskan bahwa komponen ini perhatian tanpa pamrih terhadap orang lain, penuh kepercayaan dan perasaan murah hati. Individu yang tidak memiliki keterbukaan terhadap kesepakatan sikapnya cenderung antagonism, skeptisme, dan pendekatan yang kompetitif daripada kooperatif. ${ }^{7,8}$ Dari hasil penelitian ini didapatkan nilai $P>0,05$ sehingga dapat disimpulkan tidak terdapat hubungan antara Agreeableness (keterbukaan terhadap kesepakatan) dengan skor College Maladjustment.

Skala Neuroticism (keterbukaan terhadap tekanan) menjelaskan bahwa komponen ini ukuran kepribadian orang hanya bervariasi dalam tingkatan. Tingkatan yang tinggi biasanya memiliki sikap lebih emosional, sensitif, mudah marah, dan sering mengalami emosi negative yang mencakup aspek kesedihan, kemarahan, kecemasan, kekhawatiran, kesadaran diri, kerentanan pada stres, dan kecenderungan untuk bersikap impulsif. Sebaliknya tingkatan yang rendah memiliki sikap yang lebih tenang dan emosional yang stabil. ${ }^{7,8}$ Hasil penelitian ini mendapatkan nilai $P$ $<0,05$ sehingga dapat disimpulkan terdapat hubungan antara Neuroticism (Keterbukaan terhadap tekanan) dengan skor College Maladjustment.

Pada College Maladjustment hasil analisis diperoleh bahwa paling banyak termasuk dalam kategori normal/rata-rata yaitu 45 mahasiswa $(62,50 \%)$, diikuti kategori rendah yaitu 18 mahasiswa (25\%) 
dan kategori yang paling sedikit yakni kategori tinggi yaitu 9 mahasiswa $(12,50 \%)$. Hal ini menunjukkan bahwa sebagian besar mahasiswa semester 1 Fakultas Kedokteran Program Studi Pendidikan Dokter Universitas Sam Ratulangi memiliki adaptasi emosional dan penyesuaian diri yang normal/rata-rata (Skor $\mathrm{T}$ 50-65). Hasil penelitian Palempung et $\mathrm{al}^{4}$ mendapatkan kategori normal/rata-rata lebih dominan yaitu sebanyak 74 mahasiswa diikuti dengan kategori tinggi sebanyak 26 mahasiswa dan kategori rendah sebanyak 1 mahasiswa. Hal ini membuktikan bahwa mahasiswa kedokteran lebih dominan kategori normal/ratarata sebab faktor internal dan eksternal yang terpenuhi di jenjang perguruan tinggi. Tingginya skor pada skala ini mengindikasikan adanya kemampuan adaptasi psikologik yang kurang, cemas, khawatir, merasa tidak berguna, pesimis serta orang yang suka menunda sedangkan rendahnya skor pada skala ini mengindikasikan bahwa kemampuan adaptasi psikologik yang baik serta tidak cemas. ${ }^{9}$

Penelitian ini menggunakan uji korelasi Spearman Rank untuk menguji hubungan antara variabel indeks OCEAN dan College Maladjustment. Terdapat hubungan bermakna antara Indeks OCEAN dan skor College Maladjusment, $\quad(P=0,000)$ dengan kekuatan kuat $(\mathrm{r}=-0,663$, arah negatif). Hubungan dengan arah negatif artinya hubungan keduanya berbanding terbalik, yaitu jika indeks OCEAN meningkat maka skor College Maladjustment justru menurun, demikian pula sebaliknya, jika indeks OCEAN menurun maka skor College Maladjustment justru meningkat.

Pada penelitian ini juga didapatkan hubungan bermakna antara skor Openness dan skor College Maladjustment dengan kekuatan cukup $(P=0,000 ; \mathrm{r}=-0,464$, arah negatif) yang berarti jika skor Openness meningkat maka skor College Maladjustment justru menurun, demikian pula sebaliknya, jika skor Openness menurun maka skor College Maladjustment justru meningkat. Tidak terdapat hubungan antara skor Conscientiousness dan skor College Maladjustment $(P=0,490$ dan $\mathrm{r}=0,083$, arah positif). Selain itu, terdapat hubungan bermakna antara skor Extraversion dan skor College Maladjustment $(P=0,000)$ dengan kekuatan cukup ( $\mathrm{r}=-0,418$, arah negatif). Hubungan dengan arah negatif artinya hubungan keduanya berbanding terbalik, jika skor Extraversion meningkat maka skor College Maladjustment justru menurun. Tidak terdapat hubungan bermakna antara skor Agreeableness dan skor College Maladjustment $(P=0,342)$ dan kekuatan tidak signifikan $(\mathrm{r}=0,114$, arah positif). Terdapat hubungan bermakna antara skor Neuroticism dan skor College Maladjustmen $(P=0,000)$ dengan kekuatan sangat kuat ( $\mathrm{r}=-0,767$, arah negatif). Hubungan dengan arah negatif artinya hubungan keduanya berbanding terbalik, yaitu jika skor Neuroticism meningkat maka skor College Maladjustment justru menurun.

\section{SIMPULAN}

Berdasarkan hasil penelitian pada mahasiswa Fakultas Kedokteran Program Studi Pendidikan Dokter semester 1 tahun ajaran 2018/2019 Universitas Sam Ratulangi Manado dapat disimpulkan bahwa terdapat hubungan bermakna antara indeks OCEAN dengan College Maladjustment, serta antara komponen Openness, Extraversion dan Neuroticism dengan Supplementary Scale College Maladjustment tetapi tidak terdapat hubungan bermakna antara komponen Conscientiousness dan Agreeableness dengan College Maladjustment.

\section{SARAN}

Bagi penelitian selanjutnya diharapkan menggunakan cakupan sampel yang lebih luas dan variabel lainnya seperti Anxiety Scale dan Repression Scale terhadap indeks kepribadian dasar OCEAN.

Bagi mahasiswa yang termasuk dalam kategori buruk pada indeks kepribadian dasar OCEAN dan kategori tinggi pada Supplementary Scale College Maladjustment dengan menggunakan MMPI-2 adap- 
tasi Indonesia sebaiknya melakukan konsultasi lebih lanjut kepada psikiater atau profesional lainnya dalam bidang ini.

Diharapkan hasil penelitian ini dapat dijadikan acuan untuk penelitian lanjut.

\section{DAFTAR PUSTAKA}

1. Suryabrata S. Psikologi Kepribadian (Cetakan ke 18). Jakarta: PT Raja Grafindo Persada, 2011; p. 309.

2. Adiwaty MR. Efektivitas Strategi Penyesuaian Mahasiswa Baru pada Proses Pembelajaran di Perguruan Tinggi. Jurnal NeOBis. 2015;9(1):87-96.

3. Gunawati R, Hartati S, Listiara A. Hubungan antara efektivitas komunikasi mahasiswa-dosen pembimbing utama skripsi dengan stres dalam menyusun skripsi pada mahasiswa Program Studi Psikologi Fakultas Kedokteran Universitas Diponegoro. Jurnal Psikologi Universitas Diponegoro. 2006;3(2):93-115.

4. Palempung H, Kandou LFJ, Kairupan BHR. Profil Supplementary Scales Minnesota Multiphasic Personality Inventory-2 (MMPI-2) Adaptasi Indonesia pada mahasiswa Semester 1
Tahun Akademik 2013/2014 Fakultas Kedokteran Universitas Sam Ratulangi Manado. eCl. 2014;2(2).

5. Muktamiroh H, Prabandari YS, Sastrowijoto S. Hubungan antara Kepribadian Dasar dan Kapasitas Mental dengan Persepsi, Perilaku dan Intensi Integritas Akademik. Jogjakarta: Universitas Gajah Mada; 2015.

6. Sadock BJ, Sadock VA, Ruiz P. Kaplan \& Sadock Comprehensive Textbook of Psychiatry Vol I/II (10th ed). Philadelphia: Wolters Kluwer, 2017.

7. McCrae R, Costa PT. Personality in Adulthood a Five-Factor Theory Perspective (2nd ed). New York: The Guilford Press, 2006.

8. Novikova IA. Big Five (The Five-Factor Model and the Five-Factor Theory). Russia: University of Russia; 2013. [cited 2018 Sept 08] Available from: https://www.researchgate.net/publicatio n/316094172_Big_Five_The_FiveFactor_Model_and_The_FiveFactor_Theory

9. Ben-Porath YS. Interpreting the MMPI-2-RF. London: University of Minnesota Press, 2012. 